
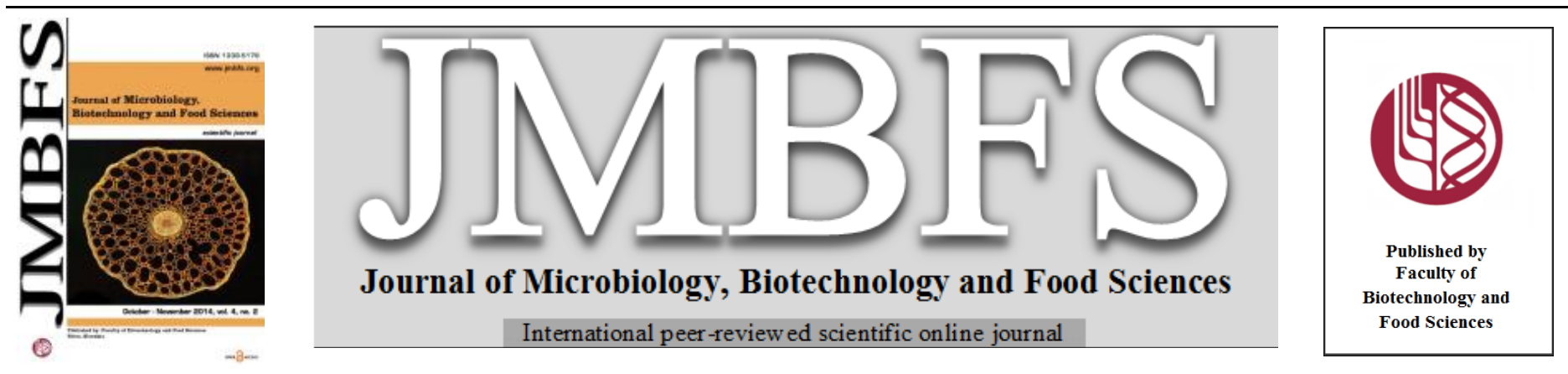

\title{
POTENTIAL IN VITRO ANTI-HELICOBACTER ACTIVITY OF BACTERIOCIN AND BACTERIOCIN-LIKE COMPOUNDS PRODUCED BY LACTOBACILLI
}

\author{
Mohammed A. Ramadan ${ }^{1,2}$, Salwa A. Megahed ${ }^{2}$, Karim M. Eltaweel $^{1}$ and Aymen S. Yassin ${ }^{2 *}$ \\ Address(es): \\ ${ }_{1}^{1}$ Department of Microbiology and Immunology, Faculty of Pharmacy, October $6^{\text {th }}$ University, $6^{\text {th }}$ of October city, Giza, 12566, Egypt. \\ ${ }^{2}$ Department of Microbiology and Immunology, Faculty of Pharmacy, Cairo University, Cairo, 11562, Egypt.
}

*Corresponding author: aymen.yassin@ pharma.cu.edu.eg

doi: 10.15414/jmbfs.2014.4.2.160-163

\section{ARTICLE INFO}

Received 11.11.2013

Revised 11. 9. 2014

Accepted 16. 9. 2014

Published 1. 10. 2014

Regular article

OPEN $\partial_{\text {ACCESS }}$

\begin{abstract}
The study was designed for screening of the potential activity of lactic acid bacteria against Helicobacter pylori and other enteropathogenic organisms. A total of 40 samples including natural cow milk and fresh infant stools were tested for the presence of lactic acid bacteria. Of these samples, 73 lactic acid bacterial isolates were recovered on MRS agar medium using the streak-plate method. Isolates inducing probiotic effect were tested under microaerophilic conditions against standard cultures of $\mathrm{H}$. pylori, Esherichia coli and Salmonella enteritidis. The data obtained showed that five isolates of lactic acid bacteria were able to produce bacteriocin or bacteriocin-like compounds. Sequencing of 16S rRNA gene revealed that five isolates belonged to Lactobacillus rhamnosus and Lactobacillus plantarum in addition to other lactic acid bacteria. The most effective isolate (LAB1) showed a marked large inhibition zone against $H$. pylori. The bacteriocin or bacteriocin like compound(s) produced by lactobacilli were further analyzed and characterized. We can conclude that probiotics might be useful in the prophylaxis or as co-therapy for treatment of $\mathrm{H}$. pylori infections.
\end{abstract}

Keywords: Lactic acid bacteria, probiotics, bacteriocins, H. pylori

\section{INTRODUCTION}

Probiotics can be defined as "live microorganisms" which when administered in adequate amounts, produce a health benefit on the host through growth and/or activity in the human body (FAO/WHO, 2001). The most commonly used bacterial strains, for food use, belong to the heterogeneous group of lactic acid bacteria (LAB), in particular lactobacilli, as well as bifidobacteria (Stanton $\boldsymbol{e t}$ al., 2003). The strongest evidence of a beneficial effect of defined strains of probiotics has been recognized using Lactobacillus rhamnosus GG and Bifidobacterium lactis BB-12 (Szajewska et al., 2001).

Helicobacter pylori is an enteric pathogen that lives in gastric mucus and survives in the acidic gastric niche of the host through urease production. $H$. pylori is considered to be the major etiological agent in chronic gastritis, peptic ulcer, duodenal ulcer and gastric cancer. One-week triple therapy using a proton pump inhibitor or ranitidine bismuth citrate combined with two antibiotics is the most frequently recommended treatment for $\mathrm{H}$. pylori infection (Malfertheiner et al., 2002). Antibiotic treatments are not always effective, as antibiotic resistance is an increasing crisis worldwide. Furthermore, it is not recommended to treat all asymptomatic people infected by $H$. pylori infection with antibiotics (Malfertheiner et al., 2002). Current anti-Helicobacter therapies using antibiotics are expensive for developing countries where most infections occur mostly because of poor hygiene. Consequently, the development of alternative methods is deemed essential (Rokka et al., 2006).

A traditional and simple way of preserving food is fermentation by LAB. A number of LAB strains primarily of dairy origin have been shown to inhibit the growth of H. pylori (Hamilton-Miller., 2003). The application of lactobacilli in food could decrease colonization of $H$. pylori in infected asymptomatic subjects, increase eradication rates when administered together with antibacterial and other drugs in symptomatic subjects, or decrease the incidence and severity of possible adverse effects due to treatments.

The objective of our study was to screen lactobacilli isolated from different milk products for their in vitro anti-Helicobacter activity and to test if the antimicrobial activity is related to the production of bacteriocin or bacteriocin like compounds.

\section{MATERIAL AND METHODS}

\section{Isolation of lactic acid bacteria}

LAB were recovered from different dairy products including (fresh natural cow milk, rayeb milk (curdled skim milk), home-made yogurt, breast milk and "refrigerator" cheese as well as infant stool by streaking plate technique on MRS medium (De Man et al., 1960), supplemented with $0.5 \% \mathrm{CaCO} 3$ and $0.05 \%$ (w/v) L-cysteine-hydrochloride (MRSC). After incubation for 2 days at $37^{\circ} \mathrm{C}$ under anaerobic conditions in an anaerobic jar with Anaerocult A gas packs (Merck, Darmstadt, Germany), only acid producing bacterial colonies were selected, indicated by the clear zone around the colonies resulting from solubility of $\mathrm{CaCO}_{3}$ by the developed acid. Colonies with different morphology were counted, picked up and purified by re-streaking on the same medium. Cell morphology, Gram staining and catalase test were performed as a preliminary screening for LAB strains. Gram-positive, non-spore forming and catalasenegative strains were selected for further studies. The selected LAB strains were maintained as stock cultures at $-80{ }^{\circ} \mathrm{C}$ in $10 \%$ skim milk (Oxoid, Basingstoke, UK).

\section{Enteropathogenic bacteria}

A standard culture of $H$. pylori ATCC 43504 strain, kindly provided by the Naval Medical Research Unit-3 (NAMRU3, Egypt), was grown on Columbia agar base (CM331 Oxoid, Basingstoke, UK) supplemented with 5\% horse blood. The inoculated plates were incubated at $37^{\circ} \mathrm{C}$ under a micro-aerophilic atmosphere containing 5\% oxygen, $10 \%$ carbon dioxide and $85 \%$ nitrogen (Oxoid generating kit no.1544995, Fisher Scientific, UK). The strain was maintained at $-80^{\circ} \mathrm{C}$ in a liquid medium with glycerol. Escherichia coli (ATCC 25922) and Salmonella enteritidis (ATCC 4931) were obtained from Microbiological Resources Center (MIRCEN, Cairo, Egypt), and they were maintained also in nutrient broth supplemented with glycerol at $-80^{\circ} \mathrm{C}$. 
Screening and detection of antimicrobial activity of lactic acid bacteria and partially purified bacteriocins

A fresh culture of the tested isolate grown in MRSC broth at $37{ }^{\circ} \mathrm{C}$ was used to inoculate MRSC broth. After incubation at $37^{\circ} \mathrm{C}$ for $24 \mathrm{~h}$, cells were removed by centrifugation at $10,000 \mathrm{x}$ f for $15 \mathrm{~min}$. The $\mathrm{pH}$ of one portion of supernatant was adjusted to 7.0 and filtered through bacterial filter (pore size $0.22 \mu \mathrm{m}$ ). The filtrates were used to evaluate antimicrobial activity using agar well diffusion method (Khunajakr et al., 2008). Positive results were recorded when the zone of inhibition of at least $1 \mathrm{~mm}$ around the wells was observed.

Bacteriocin assay was performed according to the previously recommended method (Khunajakr et al., 2008). LAB strains were grown in MRSC broth a $37^{\circ} \mathrm{C}$ for $18 \mathrm{~h}$. A cell-free solution was obtained by centrifugation of the culture at $10,000 \mathrm{x} \mathrm{g}$ for $10 \mathrm{~min}$ at $4^{\circ} \mathrm{C}$. The supernatant was then adjusted to $\mathrm{pH} 6.5-7$ using $1 \mathrm{~N} \mathrm{NaOH}$ or $1 \mathrm{~N} \mathrm{HCl}$, to rule out the inhibition through the production of organic acids. The supernatant was filtered using a bacterial filter (pore size 0.22 $\mu \mathrm{m})$. The possible inhibitory action of hydrogen peroxide was eliminated by the addition of a sterile solution of catalase $(1 \mathrm{mg} / \mathrm{ml}-$ Sigma $)$ at $25^{\circ} \mathrm{C}$ for $2 \mathrm{~h}$. The samples were then incubated in water bath at $60^{\circ} \mathrm{C}$ for $10 \mathrm{~min}$. Any residua antimicrobial activity of the treated extract was determined by the agar diffusion method.

\section{Partial purification of bacteriocin}

For purification, the sterilized and neutralized supernatant was saturated with $80 \%$ (w/v) ammonium sulfate (Merck, Darmstadt, Germany), and held for $18 \mathrm{~h}$ with stirring at $4^{\circ} \mathrm{C}$. The samples were centrifuged at $15.000 \mathrm{x} \mathrm{g}$ for $30 \mathrm{~min}$ at $4^{\circ} \mathrm{C}$ and the pellet was resuspended in $10 \mathrm{ml}$ of $10 \mathrm{mM}$ sodium phosphate buffer (Merck, Darmstadt, Germany), adjusted at pH 6.5. Further purification included dialysis using a Spectra/Por dialysis membrane with a $1 \mathrm{kDa}$ cut-off (Spectra/Por 7, Spectrum Labs, Rancho Dominguez, CA, USA) against the same buffer, overnight at $4^{\circ} \mathrm{C}$ (Yamato et al., 2003).

\section{Verification of the protein nature of the active substance}

The nature of the antimicrobial agent produced by lactobacilli was checked by enzyme treatment with the following enzymes: proteinase $\mathrm{K}(45 \mathrm{U} / \mathrm{mg})$, and trypsin $(10.6 \mathrm{U} / \mathrm{mg})$ at final concentration of $1 \mathrm{mg} / \mathrm{mL}$ in $20 \mathrm{mM}$ phosphate buffer $(\mathrm{pH} 7.0)$, catalase $(2,000 \mathrm{U} / \mathrm{mg})$, in $10 \mathrm{mM}$ potassium phosphate $(\mathrm{pH} 7.0)$. The supernatants were incubated with these enzymes at $37 \mathrm{C}^{\circ}$ for $2 \mathrm{hrs}$. Each solution was further tested against enteropathogenic bacteria in the presence of negative controls such as the initial antimicrobial supernatant and the buffered enzyme solutions of each enzyme. The supernatants were examined for their sensitivity to lipolytic and amylolytic enzymes, by lipase $(50 \mathrm{U} / \mathrm{mg})$ and $\alpha$ amylase (15 U/mg), respectively, at a final concentration of $1 \mathrm{mg} / \mathrm{mL}$ in phosphate buffer ( $\mathrm{pH}$ 7.0). Remaining activity was determined by a well diffusion assay. Untreated samples were used as control. All enzymes were obtained from (Sigma, Munich, Germany)

\section{Analysis of the 16S rDNA sequence of the most active isolate}

The oligonucleotide primers used in this study were purchased from Genosys (The Woodlands, TX, USA). Primer PAF [5' AGA GTT TGA TCC TGG CTC AG 3'] position 8-27 (using the Escherichia coli numbering system) and 536R [5 GTA TTA CCG CGG CTG CTG 3'] position 519-536 were used to amplify part of the $5^{\prime}$ region of the $16 \mathrm{~S}$ rDNA gene. Purified PCR products were sequenced using the Big Dye Terminator Reaction. Sequences determined by the automated sequencer were edited by Factura software. The sequences of about the first 500 base pairs of the 16S rDNA molecules obtained from both directions by primers $\mathrm{PAF}$ and $536 \mathrm{R}$ were assembled by Autoassembler software (All sequencing equipment and software were from Perkin-Elmer/Applied Biosystems Division, CA, USA). Unresolved bases were treated as partial observations, giving partial weight during the calculations. Base-calling and sequence assembly were confirmed manually. The assembled sequences were used to search the GenBank (National Center of Biotechnology Information, www.ncbi.nlm.nih.gov).

\section{Resistance of Lactobacillus isolates to low pH}

To determine resistance of the tested lactobacillus isolates to stomach, $\mathrm{pH} 3$ was used in vitro. For this purpose tested cultures (incubated for 16-18 h) were used Cells were harvested by centrifugation for $10 \mathrm{~min}$ at $10,000 \times \mathrm{g}$. Pellets were washed once in phosphate buffer saline $(\mathrm{pH}$ 7.2) then cell pellets were resuspended in phosphate buffer saline $(\mathrm{pH} 3)$ and incubated at $37^{\circ} \mathrm{C}$. The growth was monitored by viable count technique at time interval $0,1,2,3,4$ hours after inoculation (Çakır, 2003).

\section{Bile tolerance test}

MRS medium containing $0.3 \%$ bile (Oxoid) was inoculated with $1 \mathrm{ml}$ active cultures (incubated for 16-18 h). During the incubation for $4 \mathrm{~h}$, viable colonies were enumerated for every hour with pour plate technique (Prasad et al., 1998).

\section{RESULTS}

\section{Isolation of lactic acid bacteria from dairy and non-dairy products}

LAB were isolated from dairy products and caeca using modified MRS (Table 1). Four to five distinct colony morphologies were selected from each sample and screened for Gram-positive and catalase negative bacteria. A total of 73 LAB strains were finally selected for further analysis. Microscopic examination of the four common colony types showed different cell morphologies, cocci and rods (long-rods in chain and short rods).

Screening of lactic acid bacteria for their antimicrobial activity and the activity of the partially purified bacteriocins

The antimicrobial activity of Lactobacillus strains against the three enteropathogenic pathogens, including H. pylori, E. coli and S.enteritidis was determined using agar diffusion method. Out of 73 isolates tested, five isolates were found to exhibit antimicrobial activity against the indicator strains. The spectra of inhibition were different among the isolates tested. Isolate LB1 showed a potent antimicrobial activity against three pathogens.

The antimicrobial activity of partially purified bacteriocins of the selected Lactobacillus isolates against the three enteropathogenic pathogens, including $H$. pylori, E. coli and $S$. enteritidis was determined using agar diffusion method Clarithromycin and amoxicillin were used as positive and negative controls respectively. The results shown are the average of three replicas (Table 2).

\section{Partial 16S rDNA sequence of isolate LB1}

Among the isolated bacterial strains, isolate (LAB1) showed the most antibacterial activity and therefore was subjected molecular identification using partial 16S rDNA sequencing techniques. The sequencing results were blasted against the 16S sequences available at the NCBI (http://blast.ncbi.nlm.nih.gov) and the results showed that it was Lactobacillus plantarum based on an identity of almost $98 \%$ (Stackebrandt \& Ebers, 2007).

\section{Verification of the protein nature of the active substance}

Results of enzyme treatment on bacteriocin activity of strain Lactobacillus plantarum (LAB1) proved the proteinatious nature of anti-Helicobacter substance as the activity was lost after treatment with proteinase $\mathrm{K}$ and trypsin and was maintained after treatment with lipase and alpha amylase.

\section{Resistance of Lactobacillus plantarum to low $\mathrm{pH}$}

The growth of Lactobacillus plantarum (LAB1) was monitored by viable count technique at time interval $0,1,2,3$ and 4 hours at $\mathrm{pH} 3.0$ after inoculation and the results showed that Lactobacillus plantarum (LAB1) has the highest acid tolerance among the all isolates that tested as shown in Figure 1.

\section{Bile tolerance test of the selected Lactobacillus plantarum}

Viable Lactobacillus cells were counted by pour plate technique for four hours at time interval 0, 1, 2, 3, and 4 (Figure 2), the results showed that the isolate LAB1 identified as L. plantarum has the highest bile tolerance.

Table 1 Number of Lactobacillus isolates and their respective sources

\begin{tabular}{lc}
\hline Origin & Number of Lactobacillus isolates \\
\hline Fresh natural cow milk & 20 \\
\hline Freshly prepared rayeb milk & 15 \\
\hline Home-made yogurt & 10 \\
\hline Breast milk & 10 \\
\hline Cheese & 10 \\
\hline Infant stool & 8 \\
\hline
\end{tabular}


Table 2 Screening for antimicrobial activity of the partially purified bacteriocin produced by active isolates against $H$. pylori, E. coli and $S$. enteritidis.

\begin{tabular}{lccc}
\hline \multirow{2}{*}{ Isolate } & \multicolumn{3}{c}{ Diameter of the zone of inhibition (mm) } \\
& \multicolumn{3}{c}{ against } \\
\cline { 2 - 4 } LAB1 & H. pylori & E. coli & S. enteritidis \\
LAB2 & 14 & 15 & 14 \\
LAB3 & 14 & 15 & 14 \\
LAB4 & 12 & 14 & 13 \\
LAB5 & 12 & 14 & 12 \\
Clarithromycin & 12 & 12 & 11 \\
(Control) & 13 & $(-)$ & $(-)$ \\
\hline Amoxacillin(Control) & Resistant(-) & Resistant (-) & Resistant (-) \\
\hline
\end{tabular}

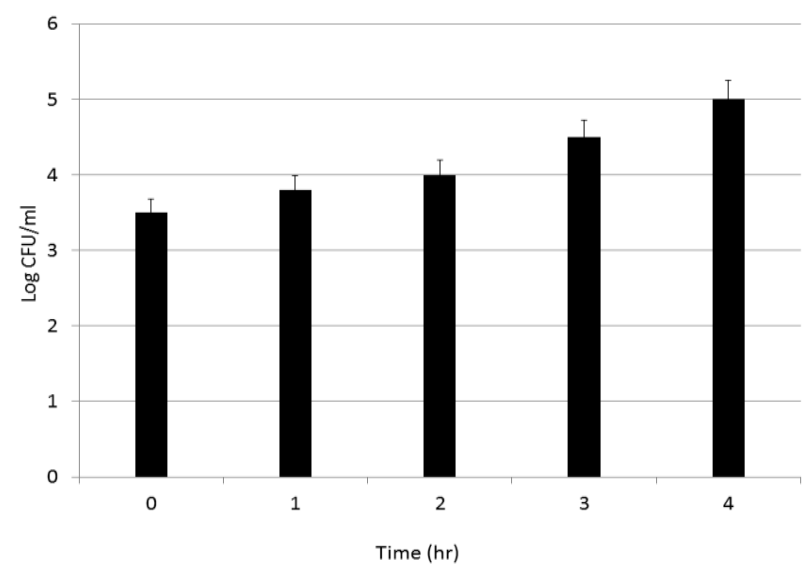

Figure 1 Resistance of Lactobacillus plantarum (LAB1)to the acidic pH (3).

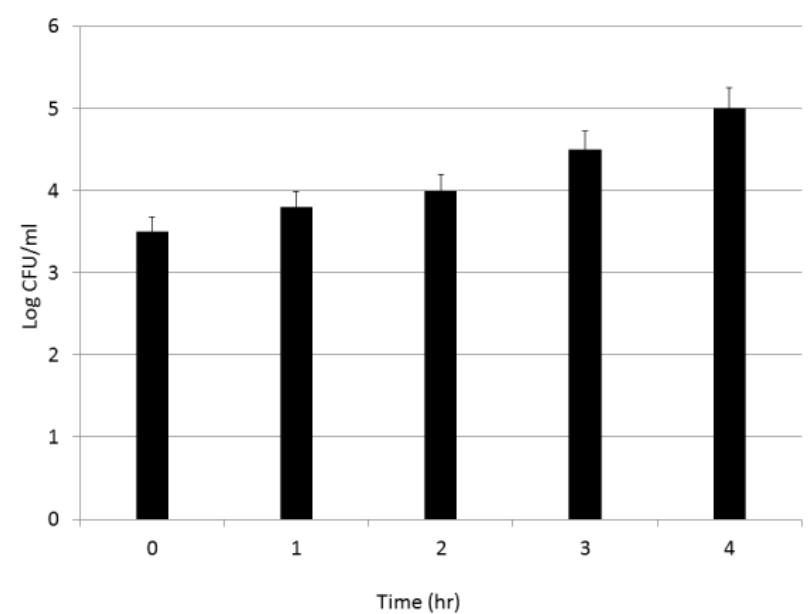

Figure 2 Effect of bile salt on the growth of Lactobacillus plantarum(LAB1)

\section{DISCUSSION}

Lactic acid bacteria represent a major class which produces bacteriocins that has become a current subject for several researches. These bacteriocins are now being explored for their potential utility in human and animal health applications, food biopreservation and agricultural uses (Todorov et al., 2011; Parada et al., 2007). Bacteriocin production by probiotics bacteria strains has indicated that it has the potential role during in vivo interactions occurring in the human gastrointestinal tract, for instance towards $H$. pylori (De Vuyst \& Leroy, 2007; Osmanagaoclu \& Beyatli, 2002).

It has been shown that some strains of LAB possess interesting health-promoting properties; one of the characteristics of these properties is the ability to combat enteric pathogens such as $H$. pylori, E. coli and S. enteritidis. This study was conducted to assess the potential in vitro activity of different lactobacilli against enteric pathogens focusing on $H$. pylori as the main etiology of peptic ulcer and gastric carcinoma. Purification and characterization of bacteriocin or bacteriocinlike substance were the main objective.

The data obtained showed that a total number of $97 \mathrm{LAB}$ isolates were recovered from different local dairy products. Of these isolates, 73 were Gram- positive, catalase negative, non- motile and non-spore forming which were identified as Lactobacillus.

Screening of these isolates for displaying bacteriocin activity against a set of enteropathogenics indicator strains including $E$. coli, S. enteritidis and H. pylor revealed that 15 isolates exhibited a marked antimicrobial activity, such activity might be explained by the production of several antimicrobial compounds like organic acids, hydrogen peroxide or bacteriocins (Labioui et al., 2005). The activity of the inhibitory agent was tested under specific conditions to eliminate the possible effect of organic acids by adjusting the $\mathrm{pH}$ of the cells-free supernatant to 6.0 and the possible effect of hydrogen peroxide was excluded by catalase treatment. The data obtained showed that five isolates produced antimicrobial activity in the neutralized cell-free supernatant against $H$. pylori, $E$. coli and Salmonella. Growth inhibition of the tested strains by the cell-free supernatant neutralized and treated with catalase was demonstrated. A marked growth inhibition was obtained by the cell-free supernatant of LAB1 and LAB2 against growth of $H$. pylori whereas the least inhibition was obtained with the cell-free supernatant of LAB5 against $S$. enteritidis.

The fact that, the cell-free supernatants (neutralized and treated with catalase) inhibited the growth of the tested strains gives evidence that the antimicrobial activity is due to the production of bacteriocins (Tatsadjieu et al., 2009).

On the basis of the above mentioned results and observations, the five selected lactobacillus strains were subjected to further identification and characterization by sequencing of $16 \mathrm{~S}$ rDNA gene. The obtained results showed that the five isolates belonged to lactobacilli.

The substances with anti-Helicobacter activity in the culture supernatant of lactobacillus isolates were found to be of proteinaceous nature as protease-treated extracts were inactive towards $H$. pylori. Even though lactic acid inhibits the urease activity of $H$. pylori, several studies have shown other substances secreted by $\mathrm{LAB}$ to be behind the mechanism of antibacterial effects (Michetti et al. 1999; Hamilton-Miller 2003). Recent studies have shown that certain lactobacilli produce secreted factors capable of reducing inflammation during $H$. pylori infection (Thiraworawong et al., 2014).

In order to exert positive health effects, the lactobacilli should resist the stressful conditions of the stomach and upper intestine that contain bile (Chou \& Weimer, 1999). Acidity is believed to be the most detrimental factor affecting growth and viability of lactobacilli, because their growth was diminished significantly below pH 4.5 (Lankaputhra \& Shah, 1995; Lankaputhra, Shah, \& Britz, 1996). Being resistant to low $\mathrm{pH}$ is one of the major selection criteria for probiotic strains (Quwehand, et al., 1999; Çakır, 2003). Since, to reach the small intestine they have to pass through from the stressful conditions of stomach (Chou \& Weimer, 1999; Çakır, 2003). Although in the stomach, pH can be as low as 1.0, in most in vitro assays $\mathrm{pH} 3.0$ has been preferred. Due to the fact that a significant decrease in the viability of strains is often observed at $\mathrm{pH} 2.0$ and below (Prasad et al., 1998). For selection the strains resistant to low $\mathrm{pH}, \mathrm{PBS}$ buffer with $\mathrm{pH}$-adjusted to 3.0 was used. The time that is taken by food during the digestion in the stomach is three hours; consequently, the isolates were detected whether they were resistant to $\mathrm{pH} 3.0$ during a period of three hours. The data showed that isolates LAB1, LAB2, LAB3 were able to survive in acidic $\mathrm{pH}$ 3.0.The strains, resistant to low $\mathrm{pH}$, were screened for their ability to tolerate the bile salt. Although the bile concentration of the human gastro intestinal tract varies, the mean intestinal bile concentration is believed to be $0.3 \% \mathrm{w} / \mathrm{v}$ and the average time taken is suggested to be $4 \mathrm{~h}$ (Prasad et al., 1998). Strains were tested in $0.3 \%$ bile during 4 hours. According to the results all of the isolates were resistant to $0.3 \%$ bile salt. LAB 1 and LAB2 were more tolerant than LAB4.

\section{CONCLUSION}

We have succeeded in isolating lactobacilli with potential anti-Helicobacter activity, the antibacterial substance was protein in nature that might belongs to bacteriocins. Several isolates were able to resist low $\mathrm{pH}$ and bile concentration usually present in the stomach, indicating their ability to be potentially used in vivo.

Acknowledgments: We would like to thank NAMRU-3 unit for supplying us with the $H$. pylori standard strain.

\section{Authors' contributions}

MAR conceived, designed and supervised the experiments

SAM analyzed the results and helped in supervising the work.

ASY analyzed the results and helped in writing the manuscript in its final form.

KME carried out the experimental procedure and drafted the manuscript.

All authors read and approved the final manuscript.

\section{Competing interest statement}

The authors declare that they have no competing interest.

\section{REFERENCES}


ÇAKIR, İ. 2003. Determination of some probiotic properties on Lactobacilli and Bifidobacteria. Ankara University Thesis of Ph.D.

CHOU, L.S., WEIMER, B. 1999. Isolation and characterization of acid and bile tolerant isolates from strains of Lactobacillus acidophilus. Journal of Dairy Science, 82, 23-31. http://dx.doi.org/10.3168/jds.S0022-0302(99)75204-5

DE MAN, J.D., ROGOSA, M., SHARPE, M.E. 1960. A Medium for the Cultivation of Lactobacilli. Journal of Applied Bacteriology, 23; 130-135.

DE VUYST, L., LEROY, F. 2007. Bacteriocins from Lactic acid Bacteria: Production, purification and food applications. Journal of Molecular Microbiology and Biotechnology, 13, 194-199. http://dx.doi.org/10.1159/000104752

FAO/WHO. 2001. Report from FAO/WHO Expert Consultation 1, 4 October 2001.

HAMILTON-MILLER, J.M.T. 2003. The role of probiotics in the treatment and prevention of Helicobacter pylori infection. International Journal of Antimicrobial Agents, 22, 360-366. http://dx.doi.org/10.1016/S09248579(03)00153-5

KHUNAJAKR, N., WONGWICHARN, A., MOONMANGMEE, D. TANTIPAIBOONVUT, S. 2008. Screening and identification of lactic acid bacteria producing antimicrobial compounds from pig gastrointestinal tracts. KMITL Science and Technology Journal, 8, 8-17.

LABIOUI, H., ELMOUALDI, L., EL YACHIOUI, M., OUHSSINE, M. 2005.

Sélection de souches de bactéries lactiques antibactériennes. Bulletin des travaux de la Société de Pharmacie de Bordeaux, 144, 237-250.

LANKAPUTHRA, E.V., SHAH, N.P. 1995. Survival of Lactobacillus acidophilus and Bifidobacterium spp. in the presence of acid and bile salts. Cultured Dairy Products Journal, 30, 2-7.

LANKAPUTHRA, W.E., SHAH, N.P., BRITZ, M.L. 1996. Survival of bifidobacteria during refrigerated storage in the presence of acid and hydrogen peroxide. Milchwissenschaft, 51, 65-69.

MALFERTHEINER, P., MEGRAUD, F., O'MORAIN, C., HUNGIN, A.P., JONES, R., AXON, A., GRAHAM, D.Y., TYTGAT, G. 2002. Current concepts in the management of Helicobacter pylori infection - The Maastricht 2-2000 Consensus Report. Aliment Pharmacol Ther, 16, 167-180. http://dx.doi.org/10.1046/j.1365-2036.2002.01169.x

MICHETTI, P., DORTA, G., WIESEL, P.H., BRASSART, D., VERDU, E., HERRANZ, M., FELLEY, C. , PORTA, N., ROUVET, M., BLUM, A. L., CORTHESY-THEULAZ, I. 1999. Effect of whey-based culture supernatant of Lactobacillus acidophilus (johnsonii) La1 on Helicobacter pylori infection in humans. Digestion, 60, 203-209. http://dx.doi.org/10.1159/000007660 OSMANAGAOGLU, O., BEYATLI, Y. 2002 The Use of Bacteriocins Produced by Lactic Acid Bacteria in Food Biopreservation. Türk Mikrobiyoloji Cemiyeti Dergisi Cilt, 32, 295-306.

PARADA, J., CARON, C., MEDEIROS, A. SOCCOL, C. 2007. Bacteriocins from lactic acid bacteria: purification, proprieties and use as biopreservatives. Brazilian Archives of Biology and Technology, 50, 521-542.

PRASAD, J., GILL, H., SMART, J., GOPAL, P.K. 1998. Selection and Characterization of Lactobacillus and Bifidobacterium strains for use as probiotic. International Dairy Journal, 8, 993-1002. http://dx.doi.org/10.1016/S0958-6946(99)00024-2

QUWEHAND, A.C., KIRJAVAINEN, P.V., SHORTT, C., SALMINEN, S. 1999. Probiotics: Mechanisms and established effects. International Dairy Journal, 9, 43-52. http://dx.doi.org/10.1016/S0958-6946(99)00043-6

ROKKA, S., PIHLANTO, A., KORHONEN, H., JOUTSJOKI, V. 2006. In vitro growth inhibition of Helicobacter pylori by lactobacilli belonging to the Lactobacillus plantarum group. Letters in Applied Microbiology, 43, 508-513. http://dx.doi.org/10.1111/j.1472-765X.2006.01998.x

STANTON, C., DESMOND, C., COAKLEY, M., COLLINS, J.K. FITZGERALD, G.F., ROSS, R, P. 2003. Handbook of Fermented Functional Foods. CRC Press: Boca Raton, 27-58. ISBN 9781420053265.

STACKEBRANDT, E., EBERS, J. 2006. Taxonomic parameters revisited: tarnished gold standards. Microbiology Today, 33, 152-155.

SZAJEWSKA, H., MRUKOWICZ, J.Z. 2001. Probiotics in the treatment and prevention of acute infectious diarrhea in infants and children: a systematic review of published randomized, double-blind, placebo-controlled trials. Journal of Pediatric Gastroenterology and Nutrition, 33 (Suppl. 2), S17-S25.

TATSADJIEU, N.L., NJINTANG, Y.N., KEMGANG, S.T., DAOUDOU, B., MBOFUNG, C. 2009. Characterization of lactic acid bacteria producing bacteriocins against chicken Salmonella enterica and Escherichia coli. African Journal of Microbiology Research, 3, 220-227.

THIRAWORAWONG, T., SPINLER, J.K., WERAWATGANON, D., KLAIKEAW, N., VENABLE, S.F., VERSALOVIC, J., TUMWASORN, S 2014. Anti-inflammatory properties of gastric-derived Lactobacillus plantarum XB7 in the context of Helicobacter pylori infection. Helicobacter, 19(22), 144 155. http://dx.doi.org/10.1111/hel.12105

TODOROV, S.D., RACHMAN, C., FOURRIER, A., DICKS, L., VAN REENEW, C., PRÉVOST, H. DOUSSET, X. 2011. Characterization of a bacteriocin produced by Lactobacillus sakei R1333 isolated from smoked salmon. http://dx.doi.org/10.1016/j.anaerobe.2010.01.004
YAMATO, M., OZAKI, K., OTA, F. 2003. Partial purification and characterization of the bacteriocin produced by Lactobacillus acidophilus YIT 0154. Microbiological Research, 158, 169-172. http://dx.doi.org/10.1078/09445013-00190 